Creative commons User License: CC BY-NC-ND

Abstracted by: EBSCOhost, Electronic Journals Service (EJS),

Google Scholar, Journal Seek, Scientific Commons,

Food and Agricultural Organization (FAO), CABI and Scopus
Journal of Agricultural Extension

Vol. 22 (1) February, 2018

ISSN(e): 24086851; ISSN(Print); 1119944X

http://journal.aesonnigeria.org

http://www.ajol.info/index.php/jae

Email: editorinchief@aesonnigeria.org

\title{
Role of Men and Women in Agro-input Business in North West, Nigeria
}

\section{https://dx.doi.org/10.4314/jae.v22i1.2}

\section{Adam, Ali Goni}

National Agricultural Extension and Research Liaison Services/ Ahmadu Bello University (NAERLS/ABU), Zaria

Email: goniadamali@yahoo.com Phone: 08027459418

\begin{abstract}
This study examined the role of male and female in agro-inputs entrepreneurship in North West, Nigeria. The specific objectives were to: describe the socio-economic characteristics of the agro-inputs dealers, assess the role of women in agro-inputs business; and identify the constraints of agro-inputs entrepreneurs. Data was obtained from forty eight (48) agro-inputs owners $(24$ wholesalers and retailers each) were purposively selected. The result revealed that the majority (62.5\%) of the agro-inputs entrepreneurs had Senior Secondary School Education. Also, majority (81.3\%) of agro-inputs business owners were men. Personal savings was indicated by majority (52\%) as the source of fund for starting the business. On staff employed, majority (65\%) men as against 35\% women employees. The type of operations carried out by the male employees indicates loading/off-loading, driving, trainings of field workers and security guards while sales and records keeping are mostly done by women (53\%). Major constraints to agro-inputs business were high taxation (45.1\%) and difficulties in sourcing foreign exchange (21.9\%). Agricultural policies aimed at encouraging more women participation in agro-inputs business and low taxation were recommended.
\end{abstract}

\section{Keywords: Agro-Inputs business, agro-inputs in north east}

\section{Introduction:}

Over the years, attempt to bridge the gap between men and women farmers as well as entrepreneurs in Nigeria, had resulted in the emergence of various women groups and organizations. They have been able to contribute immensely to the gains recorded by women in agricultural and rural development (Adegbidi, 2012). Findings from various studies revealed that women make up 60$80 \%$ of agricultural labour force in Nigeria. The responsibility placed on the shoulders of women in the rural areas to meet the daily food need of most families cannot be overemphasized. Sex plays an important role in the agricultural sector where both men and women are involved in the agricultural activities, including agro-inputs supply business that complement each other. Sex sensitive role refers to practices that consider sex in its implementation. These includes practices that take differences in sex into account, with respect to occupational accomplishments.

According to Oguntela and Mukhtar (2009) women are involved in agricultural production and other related activities such as cash cropping and animal production and usually work more hours than men. According to NBS (2013) women dominate buying and selling of agricultural products (37.0\% women participation against $10.5 \%$ for men) while males dominate in activities related 
Creative commons User License: CC BY-NC-ND

Abstracted by: EBSCOhost, Electronic Journals Service (EJS),

Google Scholar, Journal Seek, Scientific Commons,

Food and Agricultural Organization (FAO), CABI and Scopus
Journal of Agricultural Extension

Vol. 22 (1) February, 2018

ISSN(e): 24086851; ISSN(Print); 1119944X

http://journal.aesonnigeria.org

http://www.ajol.info/index.php/jae

Email: editorinchief@aesonnigeria.org

to mining and forestry products. Women are often constrained from accessing new opportunities because of poor access to resources, new markets, limited educational background and mobility restrictions as compared to men. This coupled with the fact that majority of women are poor with little access to credit or insurance and these limit their ability to best exploit market conditions (Hiroyuki, 2011). In the same vein, most rural financial programmes have been largely designed, crafted and implemented with the male head of household as the intended client and fail to recognize that women were active, productive and engaged economic agents despite their own financial needs and constraints (Mtsor and Idisi 2014).

Similarly, sex inequalities exist in decisions and management of income from Agriculture and other related activities in households (Damisa and Yohanna 2007). Also, women are often over-looked by extension service providers because they are among the poor and vulnerable and have less access to resources. Although men also face this barrier but women are more prone to it in the rural areas. Conversely, there were speculation that sex role in agro-inputs business indicates women are less represented compared to their male counterpart, (Dickson, Ekpe, and Egbe 2014). This curtails from limited information and there has not been sufficient study to validate such claims. Although, the rural poor, particularly women have little political voice and often have great difficulty organizing and expressing their preferences (Mtsor and Idisi 2014). According to Okello (2010) small and subsistence women in agro-inputs entrepreneurs have difficulty connecting to markets due to poor understanding of market dynamics and lack of access to credit to expand business.

According to World Bank (2013) women in developing countries receive less than $10 \%$ of available credit to expand trade, such as agro-inputs business. This is mainly due to lack of collateral in rural areas. For women to access financial credit, governments need to intervene to encourage the development of rural micro-credit institutions whose regulations are friendly to women. Intervention can be in the form of accepting other forms of collateral such as machinery, furniture and any other tangible assets that women own.

There is a general consensus that sex inequalities ensue in areas of ownership and access to productive resources such as land, education, extension and health which have contributed to lower employment opportunity and higher poverty levels. Given that sex matters in all domains of value chain development, which ranges from inputs supply business to production and marketing, there has been established sex issues in agricultural production. Conversely, very little is understood about sex and agro-inputs business. Based on this, the study was design to investigate sex role in agroinput business entrepreneurship in North West, Nigeria; Specific objectives were to:

i. describe the socio-economic characteristics of the agro-inputs dealers';

ii. assess the role of sex in agro-inputs business; and

iii. identify the constraints affecting agro-inputs business

\section{Methodology}

The study was conducted in North West zone, Nigeria. The zone comprises seven States, which are: Jigawa, Kaduna, Kano, Katsina, Kebbi, Sokoto and Zamfara States. It falls within semi-arid Sudan savannah zone of West Africa. The people are predominantly farmers and small to medium scale entrepreneurs'. Agriculture and petty trading were the major occupation of the communities in the states. A multistage sampling approach was used to obtain the primary respondents. Three States, 
Creative commons User License: CC BY-NC-ND

Abstracted by: EBSCOhost, Electronic Journals Service (EJS),

Google Scholar, Journal Seek, Scientific Commons,

Food and Agricultural Organization (FAO), CABI and Scopus
Journal of Agricultural Extension

Vol. 22 (1) February, 2018

ISSN(e): 24086851; ISSN(Print); 1119944X

http://journal.aesonnigeria.org

http://www.ajol.info/index.php/iae

Email: editorinchief@aesonnigeria.org

namely Kaduna, Kano and Katsina states were selected randomly. With the assistance of Agricultural Development Projects (ADP) extension staff in the selected states, two Local Government Areas (LGAs) and two communities were selected purposely. In each community four wholesalers and retailers each were purposively chosen for interview. The condition that guided the selection of communities was the availability of agro-inputs business activities. The total samples for the study were: 3 States, 6 Local Government Areas and 6 communities, $(24$ wholesalers and retailers each). Total respondents were 48 agro-input dealers. Data were collected from the respondents' using structured interview schedule, while data were analysed using descriptive statistics such as frequencies and percentages.

Table 1: States, LGAs, Communities and Agro-inputs dealers for the Study

\begin{tabular}{lllll}
\hline State & LGAs & Community & Wholesalers & Retailers \\
\hline Kano & Bunkure & Bunkure & 4 & 4 \\
& Kumbotso & Zawaciki & 4 & 4 \\
Kaduna & Sabon Gari & Sakadadi & 4 & 4 \\
& Chikun & Bagai II & 4 & 4 \\
\multirow{2}{*}{ Katsina } & Katsina & Katsina & 4 & 4 \\
& Batagarawa & Batagarawa & 4 & 4 \\
Total & $\mathbf{6}$ & $\mathbf{6}$ & $\mathbf{2 4}$ & $\mathbf{2 4}$ \\
\hline
\end{tabular}

Results and Discussion

Socio-economic Characteristics of Agro-inputs Dealers

Table 1 indicates that most of the farmers were male $81.3 \%$ reflecting that the agro-dealers' were responsible male profiteering to cater for the wellbeing of their family. The findings is in agreement with Ogunlela and Mukhtar (2009) report that women in the rural areas had very limited access to marketing of agro-chemicals and reproductive resources. The findings also revealed that most of the respondents $56.3 \%$ were between $31-40$ years of age, indicating that the inputs dealers were headed by men in their active age. Only $10.4 \%$ were above the age of 50 years. Educational level of the respondents' showed that more than half of the respondents' $62.5 \%$ had secondary education level. This was followed by those with tertiary level of education, representing $20.8 \%$. According to Ayansina, (2011) small-scale resource-poor in Nigeria are either non-literate or have low level of education. Extension messages should therefore be prepared with this in mind in order to take care of all and sundry involved in a particular programme of development. Level of educational attainment can enhance the capacity of the agro-inputs dealers to access relevant information on inputs usage and marketing (Kotze, 2003).

Similarly, majority of the agro-inputs dealers $52.0 \%$ sourced their funds for stating agro-inputs business through personal savings. Those who source through sales of farm produce constitutes $22.9 \%$, while those sourced from cooperatives represents only $6.3 \%$ of the respondents. 
Creative commons User License: CC BY-NC-ND

Abstracted by: EBSCOhost, Electronic Journals Service (EJS), Google Scholar, Journal Seek, Scientific Commons,

Food and Agricultural Organization (FAO), CABI and Scopus
Journal of Agricultural Extension

Vol. 22 (1) February, 2018

ISSN(e): 24086851; ISSN(Print); 1119944X

http://journal.aesonnigeria.org

http://www.ajol.info/index.php/jae

Email: editorinchief@aesonnigeria.org

Table 2: Socio-economic characteristics of the respondents

\begin{tabular}{ll}
\hline Variable & Percentage $(\mathbf{n}=\mathbf{4 8})$ \\
\hline Sex & \\
Male & 81.3 \\
Female & 18.7 \\
Age (years) & \\
Less than or equal to 20 & 4.1 \\
$21-30$ & 12.5 \\
$31-40$ & 56.3 \\
$41-50$ & 16.7 \\
Above 50 & 10.4 \\
Educational level & \\
No formal education & 4.2 \\
Primary education & 12.5 \\
Secondary education & 62.5 \\
Tertiary education & 20.8 \\
Sources of funds for business & \\
Sales of Farm Produce & 22.9 \\
Loan & 14.6 \\
Personal Savings & 52.0 \\
Parents/Relatives & 4.2 \\
Cooperative & 6.3 \\
\hline
\end{tabular}

Source: Field Survey, 2016

Participation of Male and Female in Agro-inputs Business

Table 3 showed the level of participation by sex in agro-inputs industry. The ownership of Agroinputs business by sex showed that $81.3 \%$ belong to men as compared to $18.7 \%$ belonging to women. Also, seen in the table is staffing which indicated that, majority $64.8 \%$ were men as against $35.2 \%$ women employees. This implies that men dominated the business of agro-inputs. Similarly, sex of customers showed that $70 \%$ were men, while women constitutes $30 \%$ of the customers. The findings is in agreement with the findings of Mtsor and Idisi (2014) which stated that women are mainly involved in the production, processing and trading of such food crops as maize, rice, cassava, yam and palm oil, they are rarely connected with agro-inputs trading.

Table 3: Participation in agro-inputs business by sex

\begin{tabular}{ll}
\hline Variable & Percentage \\
\hline Ownership of Agro-input Business & \\
Men & 81.3 \\
Women & 18.7 \\
Sex of Employees & \\
Men & 64.8 \\
Women & 35.2 \\
Sex of Customers & \\
Men & 70 \\
Women & 30 \\
\hline
\end{tabular}

Source: Field Survey, 2016 
Creative commons User License: CC BY-NC-ND

Abstracted by: EBSCOhost, Electronic Journals Service (EJS),

Google Scholar, Journal Seek, Scientific Commons,

Food and Agricultural Organization (FAO), CABI and Scopus
Journal of Agricultural Extension

Vol. 22 (1) February, 2018

ISSN(e): 24086851; ISSN(Print); 1119944X

http://journal.aesonnigeria.org

http://www.ajol.info/index.php/iae

Email: editorinchief@aesonnigeria.org

\section{Perceived Male and Female Disparity in Agro-inputs Trade}

Result in Table 4 showed that the majority of the Agro-inputs dealers' indicated difference among their customers based on the quantities in purchases and sales by sex. Sixty five percent of purchases were made by men as compared to $35 \%$ by women. Almost all $89.6 \%$ of the Agro-inputs owners indicated their willingness to give inputs to their customers on credit with some conditions. However, the responses on repayments of credits on scheduled indicated $58.3 \%$ women being credit worthy as compared to $41.6 \%$ men as presented in Table 4 .

Table 4: Perceived disparity in purchases and sales of agro-inputs by sex

\begin{tabular}{ll}
\hline Variable & Percentage \\
\hline Differences in Purchases by sex & 64.6 \\
Yes & \\
Disparity in Purchases & 83.3 \\
Men & 16.7 \\
Women & \\
Sales on credit to customers & $\mathbf{8 9 . 6}$ \\
Yes & \\
Disparity in repayment of credit on scheduled & 41.6 \\
Men & 58.3 \\
Women & \\
\hline
\end{tabular}

Source: Field Survey, 2016

\section{Types of Operations in Agro-input Business}

Figure 1 shows the type of operations carried out by the employees according to sex in agro-inputs business. Operations like loading/off-loading, driving, trainings of field workers and security guards were all performed by men. Similarly, sales and records keeping operations are mostly executed by women 53\% as compared men 47\%. Implication of the findings is that men are involved in most of the tedious job compared to women who are primarily engaged in such work as sales and records keepings.

\section{Operations in Agro-inputs business according to Sex}

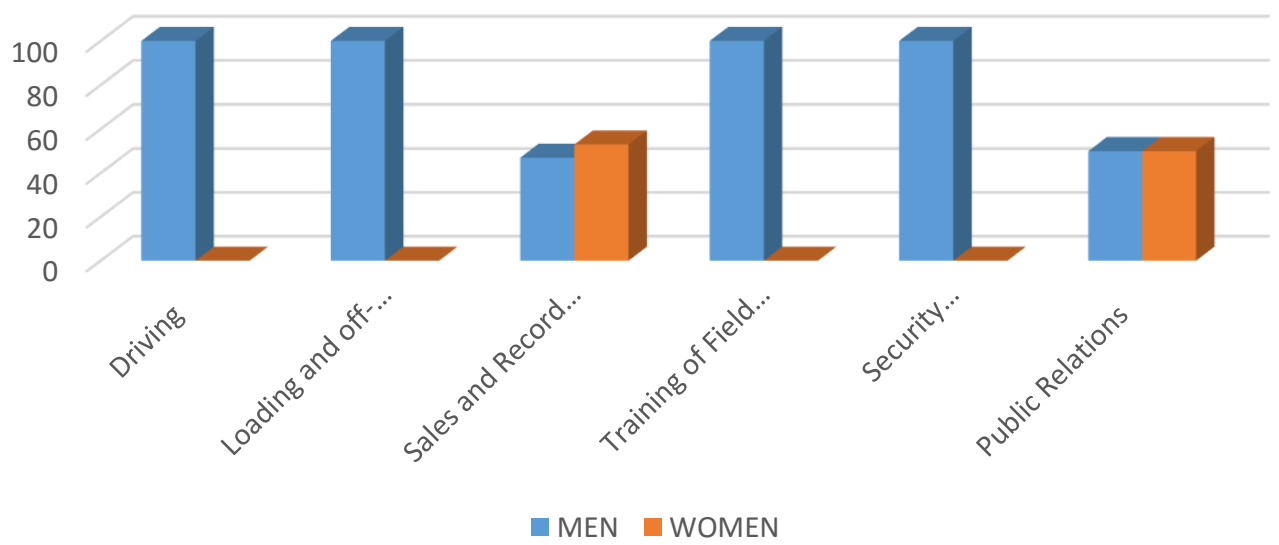

Figure 1: Different operations in agro-inputs business by sex. 
Creative commons User License: CC BY-NC-ND

Abstracted by: EBSCOhost, Electronic Journals Service (EJS),

Google Scholar, Journal Seek, Scientific Commons,

Food and Agricultural Organization (FAO), CABI and Scopus
Journal of Agricultural Extension

Vol. 22 (1) February, 2018

ISSN(e): 24086851; ISSN(Print); 1119944X

http://journal.aesonnigeria.org

http://www.ajol.info/index.php/jae

Email: editorinchief@aesonnigeria.org

\section{Constraints Affecting Agro-Inputs Business}

Table 5 reveals that the majority $45.1 \%$ of the respondents indicated high taxation was the main constraints affecting agro-inputs business in the study area. While $21.9 \%$ indicated difficulties in sourcing for foreign exchange as a factor affecting their business. Similarly, $18.2 \%$ of the responses shows lack of mobility was constraints affecting agro-inputs business. The findings may not be unconnected with the current issues on foreign exchange and economic downturn the country faced. Empowering women requires transformation in the way governments devise budgets, make and enforce laws and policies on trade that may stimulate small and medium, enterprises entrepreneurs', including agro-inputs business.

Table 5: Constraints affecting agro-inputs business

\begin{tabular}{lll}
\hline Variables & Percentage & Rank \\
\hline Lack of mobility & 18.2 & $3^{\text {rd }}$ \\
High Taxation & 45.1 & $1^{\text {st }}$ \\
Foreign Exchange & 21.9 & $2^{\text {nd }}$ \\
Inadequate funds to expand business & 14.6 & $4^{\text {th }}$ \\
Lack of market information & 8.8 & $5^{\text {th }}$ \\
\hline
\end{tabular}

* Multiple responses

\section{Conclusion and Recommendation}

. There were low women participation in most activities compared with their men counterpart. However, women were more involved in sales and record keeping activities. Women should have equal access to productive resources to be able to participate in agro-inputs business and other income generating activities. This may lead to employment opportunity and reduce poverty level among women and youth. Furthermore, the study revealed high taxation cost as the major constraint affecting agro-inputs business in the study areas. Agricultural policies aimed at encouraging and promoting more women participation in agro-inputs business with low taxation incentive. Due attention to be given to women groups by empowering them in productive activities and entrepreneurship development so as to contribute in agro-inputs business activities. Women be given special courtesy in the Anchored Borrowing programme of the FGN/CBN and by reducing the administrative bottlenecks associated with bank loans. The government should put in place a law to compel private organizations and other institutions to mainstream sex in their operations.

\section{References}

Adegbidi A (2012). Linking small-scale farmers to markets in Benin: a failure of ICT-based initiatives? Evidence from case studies, Journal of Research in International Business and Management. (ISSN: 2251-0028) Vol. 2(11) pp. 261-272, November.

Ayansina, S. O., (2011). Farmers' Perception of Public and Private Extension Services in South Western Nigeria: Thesis in the Department of Agricultural Extension and Rural Development, University of Ilorin. 
Creative commons User License: CC BY-NC-ND

Abstracted by: EBSCOhost, Electronic Journals Service (EJS),

Google Scholar, Journal Seek, Scientific Commons,

Food and Agricultural Organization (FAO), CABI and Scopus
Journal of Agricultural Extension

Vol. 22 (1) February, 2018

ISSN(e): 24086851; ISSN(Print); 1119944X

http://journal.aesonnigeria.org

http://www.ajol.info/index.php/jae

Email: editorinchief@aesonnigeria.org

Damisa, M.A. and Yohanna M. (2007). Role of rural women in farm management decision making process: Ordered Probit Analysis Trends in Applied Science Research, 2(3): 241-145.

Dickson E. Ekpe, A. E. and Egbe I.J. (2014). Women, gender equality in Nigeria: A critical analysis of socioeconomic and political (gender issues): Journal Research in Peace, Gender and Development (JRPGD) Vol. 4(1) pp. 15-20. FDOI: http:/dx.doi.org/10.14303/ jrpgd 2014.009 Available online http://www. interesjournals.org/ JRPGD

Hiroyuki, T. (2011). Assessing input-specific knowledge gaps in farmers' demand for agricultural inputs Seed and irrigation technologies in Nigeria. African Journal of Agricultural Research, 6(9), 20722077.http://dx.doi.org/10.1596/978-0-8213-6880-0

Kotze, D.A., (2003). Role of women in the household economy, food production and security: Policy guidelines Outlook on Agriculture, 32:111-121.

Mtsor, Y.G. and Idisi, P.D. (2014). Gender inequality and women participation in agricultural development in Nigeria. Merit Research Journal of Education and Review. 2(11):269-301.

National Bureau of Statistics (2013). Gender Dimensions to Livelihoods in Nigeria: General Household Survey Panel (GHS-Panel). Available at www.nigerianstat.gov.ng .

Ogunlela Y.I. and Mukhtar A. A. (2009). Gender Issues in Agriculture and Rural Development in Nigeria: The Role of Women. Humanity and Social Sciences Journal 4(1): 19-30, 2009 ISSN 1818-4960.

Okello, J. (2010). Effect of ICT-based MIS projects and the use of ICT tools and services on transaction costs and market performance: The case of Kenya. Unpublished draft.

World Bank (2013). Women, Business and the Law. Creating Economic Opportunities for Women (http://wbl.worldbank.org/data/exploreeconomies/nigeria/2013 .accessed 10 October 2016). 